\title{
MEDIATIZATION OF ISLAMIC DOCTRINE IN A NEW ERA OF DIGITAL INDONESIA: The Case of Ḥadīth on Dajjāl
}

\author{
D. I. Ansusa Putra, ${ }^{1}$ Agus Firdaus Chandra ${ }^{2}$ \\ 1Universitas Islam Negeri Sulthan Thaha Saifuddin, Jambi - Indonesia, \\ 2Universitas Islam Negeri Sultan Syarif Kasim, Riau - Indonesia \\ e-mail: 1ansusa@uinjambi.ac.id; 2agus.firdaus.chandra@uin-suska.ac.id
}

\begin{abstract}
This research is a study of the mediatization of the hadīth on Dajjall (the anti-Christ) in the context of media culture. Mediatization of the hadith through illustrations allows every Muslim to understand the stages and events that will occur at the End of the Time (Ākhir al-Zamān). Such hadīth is pre-actual doctrinal texts in Islam. This article uses the theory of mediatization that has a close link with the discipline of media studies and religiosity. We argue that the hadith illustration as an expression of religious beliefs is a continuation of the massive use of technology in understanding religious doctrines. On the other hand, the illustration of the hadìth. Hadìth on the Dajjāl in digital media has formed a new pattern in the understanding of hadith from abstract-imaginative to concreteimaginative. The illustration of the Dajjāl has become an indication of the widespread role of the media in the spread of Islamic doctrines, and its changing role from being dominated by the texts to being dominated by the logic of religion. This research uses the theory of mediatization with the approach of media culture. The data is obtained from footage of such hadith documentary airing on YouTube accounts. These shows usually refer to preachers who are concerned with conveying the contents of the hadith.
\end{abstract}

\begin{abstract}
Abstrak: Penelitian ini merupakan studi tentang fenomena mediasisasi hadis tentang Dajjāl dalam konteks budaya media. Mediasisasi hadits melalui ilustrasi memungkinkan setiap muslim dapat memahami tahapan dan kejadian yang akan terjadi di akhir zaman. Hadis tentang Dajjāl merupakan doktrin pre-aktual dalam Islam. Artikel ini menggunakan teori mediasisasi yang memiliki kaitan erat dengan disiplin media studies dan religiusitas. Kami berargumen bahwa ilustrasi hadits tentang Dajjāl sebagai bentuk ekspresi keyakinan agama merupakan kelanjutan dari masifnya penggunaan teknologi dalam memahami doktrin keagamaan Di sisi lain, ilustrasi hadis tentang Dajjāl di media digital ini telah membentuk pola baru dalam pemahaman hadis dari abstrak-imaginatif menjadi konkret-imaginatif. Ilustrasi hadis tentang Dajjāl menjadi indikasi meluasnya peran media dalam penyebaran materi Islam, dan perubahan perannya dari didominasi menjadi mendominasi logika agama. Penelitian ini menggunakan teori mediasisasi dengan pendekatan budaya media. Data-data diperoleh dari cuplikan/tayangan hadits tentang Dajjāl secara documenter tayang di akun-akun YouTube. Tayangan ini biasanya merujuk kepada pendakwah yang konsen menyampaikan konten-konten hadis tentang Dajjāl.
\end{abstract}

Keywords: hadīth on the End of Time; mediatization Islamic doctrine, Dajjāl; fitna 


\section{A. Introduction}

Mediatization happens in the whole life of human aspects. Mediatization in this context means a social change in a contemporary society rooted in media technology. ${ }^{1}$ Mediatization becomes a subject that brings various ideologies even religion. Currently, media information that is generated from new technology brings new content of religious values. In this context, it turns out to bring up a new theology approach. According to Irina A. Ushanova in Mediatization of Communication: from Concept to Theory, known that Mediatization is a way to find out medial communication in people's culture. Mediatization emphasizes two discussions, first, the interrelation between change and communication. Second, they are integrated into the structure, process, production, publications, daily life, and social identity. ${ }^{2}$

Mediatization was first introduced by Friedrich Krotz in his Mediatized world. This theory focuses on the behavior of mass communication changes. Where, the media dominated by political, religious, social, cultural interests. Currently, the media dominates political, religious, social and cultural logic. ${ }^{3}$ The pattern of media dominance is seen in all social activities in looking for religious sources and understanding of theology through media. ${ }^{4}$ New media brings new values to understand religion. The presence of new media makes the majority of people tend to make religious information through social media as an authority. It can be seen through the diverse behavior of Muslim society when looking for Islamic teaching content by accessing Qur'ān and Hadìth that are provided on website, application and social media.

Online media or youtube as a mediator of consuming information can be also used to spread various Islamic da'wah videos. Currently, da'wah is not only done in conventional ways like a lecture, oration on the mimbar (podium). Those

\footnotetext{
${ }^{1} \mathrm{~K}$ Lundby, "Mediatization as Key," in Mediatization: Concept, Changes, Consequences (New York: Peter Lang, 2009).

2Irina A. Ushanova, "Mediatization of Communication: From Concept to Theory," Journal of Siberian Federal University. Humanities \& Social Sciences 11, no. 8 (2015): 2703-12, https://doi.org/10.17516/1997-1370-2015-8-11-2703-2712.

3 Ushanova.

${ }^{4}$ AG. Eka Wenats Wuryantai, "Digitalisasi Masyarakat: Menilik Kekuatan dan Kelemahan Dinamika Era Informasi Digital dan Masyarakat Informasi," Jurnal Ilmu Komunikasi 1, no. 2 (2004): 131-42, https://ojs.uajy.ac.id/index.php/jik/article/view/163.
} 
ways are not effective anymore to be done. Da'wah or the spreading of Islam would be more effective by using new media. ${ }^{5}$ Da'wah material also exceeds the limit of time and space in seconds. This makes religion and media have a significant correlation in contemporary society.

One of hadith material that often is spread through media technology is related to the Hadìth on Dajjāl. This hadith has illustrated the condition of the End of the Time (ākhir al-zamān) in the form of presentation or documentation, based on the content of hadith in Islamic literature. From the preliminary research, it is obtained that illustration of the hadìth on Dajjāl possessed as great signs of yawm al-qiyāmah. ${ }^{6}$ Dajjāl means a liar or a man who hides the truth. By surveying Islamic narratives, it can be said that Dajjall is someone who rejects the truth and replaces it with untruth. The Dajjāl is come to examine people in their faith. ${ }^{7}$

This study tried to construct the understanding of the hadìth on Dajjāl emergence and events that occur when Dajāl comes through video content, text, illustration analysis from YouTube account. From the preliminary observation found that several YouTube accounts that produce many illustrations of the hadìth on Dajjāl hadìth and have been watched by millions of viewers, namely: the news of the end times, UZMA Media TV Channel, Qaf Media Channel, AlHujjah Channel, Nota Hikmah, etc. While other channels/accounts only take from the accounts organized above. So, two categories of accounts spread endtime illustrations, first, organized accounts, such as "Kabar Ākhir al-zamān", UZMA Media TV Channel, Qaf Media Channel. Second, an unorganized account that only continues the content of hadith on the End of the Time on the media organized above. This study only focuses on showing illustrations of the content of hadith on Dajjāl. So, the preaching content on YouTube accounts is not included in the focus of this study.

This discourse is important to be studied because, from preliminary research, it was found that religious information there is no article discusses

\footnotetext{
5Eko Sumadi, "Dakwah dan Media Sosial: Menebar Kebaikan tanpa Diskrimasi," At-Tabsyir: Jurnal Komunikasi Penyiaran Islam 4, no. 1 (2016): 173-90, https://doi.org/10.21043/attabsyir.v1i2.2912.

${ }^{6}$ Muslim bin al-Hajajāj Abū al-Hasan al-Qusyairy al-Naisyabūry, Șaḥ̄ḥ Muslim, Juz 4 (Beirut: Dār al-Fikr, n.d.), h. 2225.

${ }^{7}$ Maryam Bakhtyar, "Adaptation and Comparison of Dajjal (Antichrist) in Islam with in Christianity," Journal of Islamic Studies and Culture 2, no. 2 (2014): 71-81.
} 
Dajjāl as illustrated on YouTube. ${ }^{8}$ There are articles discuss mediatization of Islamic lectures like Moch Fakhruroji entitled his article Mediatization of religion in "texting culture": self-help religion and the shifting of religious authority. ${ }^{9}$ Another work is Agama di Era Media: Kode Religius dalam Industri Televisi Indonesia (Religion in Media Era: Religious Code in Indonesian Television Industry) by Iswandi Syahputra. ${ }^{10}$ Iswandi here tracked religious words that is the most mentioned in Indonesian television media. The last, work by Ratna Istriyani and Yuliatun entitled Media: Causes and Strategies to Overcome Islamophobia (Psychological and Sociological Study). ${ }^{11}$

This article states a different side of those works, this study tried to see the correlation between media stream with religious information which was preactual. Pre-actual here related to information and religious belief that does not occur yet.12 This belief is still predictive like the belief of the signs of the End of the Time in Islam. This distinguished the focus of this study with others, the different focus of this study would result in different conclusions from the previous studies.

This study uses the mediatization theory. Mediatization is useful to see religious phenomena in contemporary media. In this context, the mediatization theory here becomes one of the interesting things to see the phenomena and socio-cultural practice in which their presences are inspired by hadith in the past and become a practice in the present. Religious modernity practice is a meeting point between religious norms and social context. In this context, the understanding and belief that come from the hadìth on Dajjāl are poured in the modernity paradigm by using new media through the illustrations and suitability with the current context.

\footnotetext{
${ }^{8}$ Agus Mulyono, Kasus-Kasus Aktual Kehidupan Keagamaan di Indonesia (Jakarta: Badan Litbang dan Diklat Puslitbang Kehidupan Keagamaan Jakarta, 2015).

${ }^{9}$ Moch Fakhruroji, “Mediatization of Religion in 'Texting Culture': Self-Help Religion and the Shifting of Religious Authority," Indonesian Journal of Islam and Muslim Societies 5, no. 2 (December 10, 2015): 231, https://doi.org/10.18326/ijims.v5i2.231-254.

${ }^{10}$ Iswandi Syahputra, "Agama di Era Media: Kode Religius dalam Industri Televisi Indonesia," Esensia: Jurnal Ilmu-Ilmu Ushuluddin 17, no. 1 (2016): 125-38, https://doi.org/10.14421/ esensia.v17i1.1283.

${ }^{11}$ Ratna Istriyani and Yuliatun Yuliatun, "Media: Causes and Strategies to Overcome Islamophobia (Psychological and Sociological Study)," QIJIS (Qudus International Journal of Islamic Studies) 4, no. 2 (2016): 201-2017, https://doi.org/10.21043/qijis.v4i2.1759.

${ }^{12}$ Abdul Fattah Idris, "Hadis Prediktif dalam Kitab al-Bukhari," Jurnal Theologia 24, no. 1 (2013): 285-306, https://doi.org/10.21580/teo.2013.24.1.325.
} 

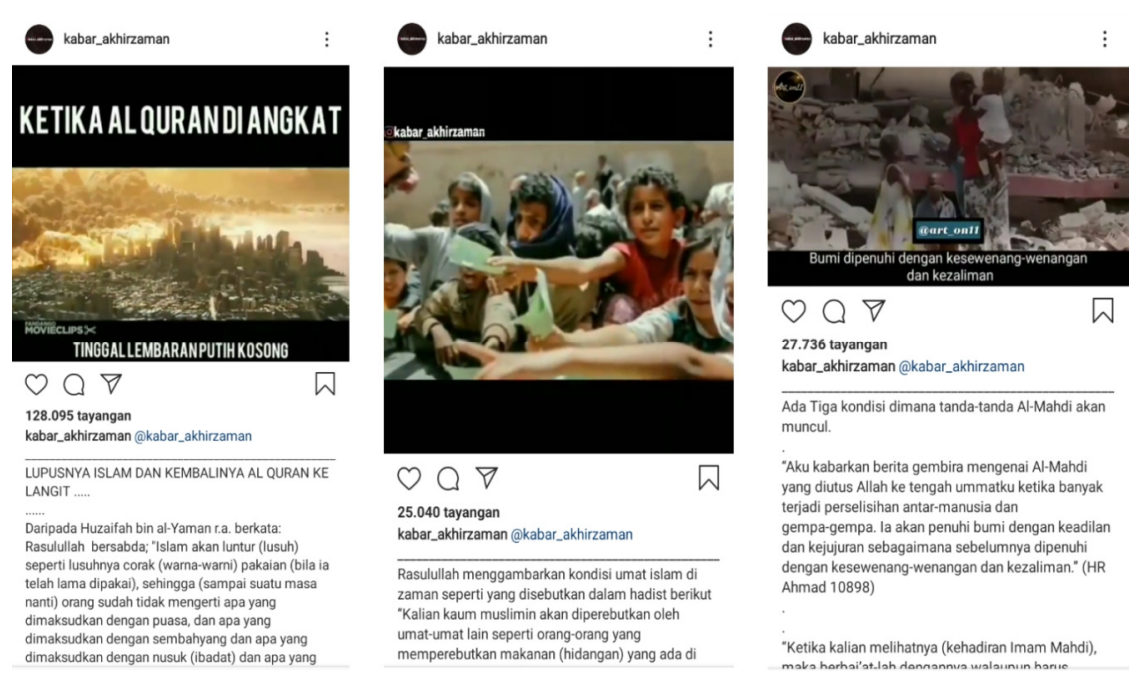

\section{B. Mediatization in Indonesia}

In the past, the media was a subordinate of religion, because the communication process is done centrally by religious institutions, in particular religious instruments, like khutbah and da'wah. Muslims use varieties of media that are more effective for use in $d a^{\prime} w a h$. For example, through religious lectures, art, or even through writings that contain Islamic teachings derived from the Qur'an and hadith as the main material. The choice of $d a^{\prime}$ wah media must consider the segmentation of mad'ū (object) because one media can be effective for one particular community but can also be ineffective for another community.

Now a day, the method of $d a^{\prime} w a h$ also rises to develop. In the current era, preaching is packaged in such a way as to make it look more attractive. Like through religious songs (qasidah) including lectures that are displayed in television media and internet media, also through various applications that can be used as a means to support the effectiveness of the $d a^{\prime}$ wah process. It is a form of human adaptation to the socio-political phenomena and conditions that are developing in their communities to measure the achievement of communication purposes. ${ }^{13}$ 2006), 12.

13Johannes Müller, Perkembangan Masyarakat Lintas Ilmu (Jakarta: Gramedia Pustaka Utama, 
The emergence of information technology gives an impact on the emergence of changing patterns of Islamic teaching. For Islamic da'wah activists in Indonesia to change the conventional pattern of $d a^{\prime} w a h$ to information technology-based or to combine conventional da'wah with propaganda based on information technology. As a result, various Islamic organizations did not miss to create official sites or even social media as a means of delivering da'wah. This change shows the role of the media is greater than the previous role. Religion is currently dominated by the logic of the media. Media logic demands an Islamic mission that is more effective, massive and simple. This change in position between religion and the media so-called mediatization.

Mediatization is seen as a process of orientation from modernity and globalization. when the media becomes an independent institution with its logic. Other social institutions -in this case, religion- must follow that logic. Therefore, the media has become dominated by religious logic. But now, after making massive changes, the media becomes more widespread and the logical of the media is now spread to religious teachings. At the same point, religion must accommodate media logic. Media logic itself refers to the function of the media as "Medium", and construct symbolic resources.

So the transition of the superiority of religious material to be inferior to the media and information technology has changed the pattern of religious material delivery today. Particularly, hadìth grows significantly with globalization. The global era makes society easy to obtain information across time and place. This globalization changes the information phenomenon enables hadith to be enjoyed by many people. Through the development of internet technology, hadith scholars welcome the direction of the hadith's golden age simultaneously. Currently, muhaddithin offers various technology approach to make it easier to collect hadìth and spread hadìth information to society.

The teaching of the hadith today has followed the concrete-imaginative as the logic of media. One of the evidence is the phenomenon of the hadith illustration on Youtube. The illustration is generally showing audio-visual in describing events based on hadith text which is claimed as a religious symbol. It is chosen one theme related to the current issue in Muslim society. Besides, it is also completed by showing Qur'an verses and hadīth quotation in-display scene (DS). Including verse or hadìth quote was a must in IT-based hadìth 
illustration..$^{14}$ Beside to fulfill the requirements of religious spreading or da'wah, including hadìth and Qur'an verses quote was to justify for the illustrated content. This justification could strengthen the argument in hadith illustration to all the mad'u/da'wah object. On that post did not only present text related to hadìth, but also Muslim illustration in doing their work and pray. That post also accompanied with religious music instrument so it added a sense of solemnity in enjoying that 5-minutes video. From the example above, it was understood that those short videos still mention the reference and hadith source..$^{15}$ Although it did not mention the narrator in detail. The mediatization of hadith with this kind of illustration does not contain fully hadith (accompanied with sanad, matn and narrator). But at least, the mediatization of hadìth through illustration can help Muslim society in tracing hadìth that related to the problem sought.

Hadith can be understood that the using of hadith illustration is done for various reasons. The goal of shiar/da'wah, imaging, and mainstreaming certain theme are to counter negative issues that related to religion. ${ }^{16}$ It is because what is illustrated in the display scene has suitability with the problem or event that is faced by the religious community. Observing the mediatization of hadith phenomenon that has been merged with popular culture in contemporary society. ${ }^{17} \mathrm{At}$ this point, religious value and popular culture now become two things that support each other. This hadith illustration also makes religious figures are increasingly loved in expressing themselves in popular culture characteristics. And then, that ustadh lecture is used as audio filler in that hadìth illustration. ${ }^{18}$

\footnotetext{
14Yedi Purwanto, Muhamad Taufik, and Asep Wawan Jatnika, "Peran Teknologi Informasi dalam Perkembagan Dakwah Mahasiswa," Jurnal Sosioteknologi 16, no. 1 (2017): 94-109, https://doi.org/10.5614\%2Fsostek.itbj.2017.16.1.8.

${ }^{15}$ Musthofa Musthofa, "Prinsip Dakwah via Media Sosial," Aplikasia: Jurnal Aplikasi Ilmu-Ilmu Agama 16, no. 1 (2016): 51-55, https://doi.org/10.14421/aplikasia.v16i1.1175.

16Faradillah Iqmar Omar, Nor Azlili Hassan, and Iza Sharina Sallehuddin, "Role of Social Media in Disseminating Dakwah (Peranan Media Sosial dalam Penyebaran Dakwah)," in Islamic Perspectives Relating to Business, Arts, Culture and Communication, ed. Roaimah Omar, Hasan Bahrom, and Geraldine de Mello (Singapore: Springer Singapore, 2015), 47, https://doi.org/ 10.1007/978-981-287-429-0_5.

${ }^{17}$ Hadri Hasan, "Contemporary Religious Movement in Indonesia: Study of Hijrah Festival in Jakarta in 2018," Journal of Indonesian Islam 13, no. 1 (2019): 230-65, https://doi.org/ 10.15642/JIIS.2019.13.1.230-265.

${ }^{18}$ Ariel Heryanto, Identity and Pleasure: The Politics of Indonesian Screen Culture (Singapore: National University of Singapore (NUS) Press, 2014).
} 


\section{C. Ḥadīth on Dajjāl}

Understanding the hadīth on Dajjāl will not be complete without following the scholar's discourses about predictive and technical hadìth. ${ }^{19}$ This discourse has been discussed for a long time by some scholars like Fazlur Rahman in his Islam and Modernity: Transformation of an Intellectual Tradition. Rahman assumed that the matn of predictive and technical hadith did not come from The Prophet but it was a formulation from the next generation..$^{20}$ Rahman's view on this context continued Schact's critics. Although in his book Islam, Rahman refused Schact's view about the streams of Islamic law, but Rahman accepted Schact's thought about the spreading of hadith and about Schact's Projecting Back theory. ${ }^{21}$ However, Schact and Fazlur Rahman's argument about the criticism of the matn of hadith above has been confronted by some Muslim scholars like Muhammad Abu Zahrah, Musthafa Azami, Zafar Ishaq Ansari. Among the Orientalists themselves, Schact's theories did not only get a positive reaction, because some others, but some did not agree or even criticized the theories offered by Schacht. For instance Noel Coulson, Michael Cook, Harald Moztki, and Rubin. ${ }^{22}$

Fazlur Rahman with his critics of matn identified predictive hadith. The predictive hadīth that Rahman meant was hadìth that contained forecast news in the future. ${ }^{23}$ Either direct or indirect, so it could not be accepted as hadith which came from The Prophet. According to Rahman, hadith contextually had to be interpreted situationally and adapted to the situation at the present (historical-sociological). ${ }^{24}$ Rahman's rejection toward predictive hadìth s was based on historical proofs that were real contained good forecast either direct or

${ }^{19}$ Faiz Karim Fatkhullah, Tajudin Nur, and Undang Ahmad Darsa, “The Reception of Dajal Story in the Saifu Ad-Dharib," Humanus: Jurnal Ilmiah Ilmu-Ilmu Humaniora 17, no. 1 (2018): 37-52, https://doi.org/10.24036/humanus.v17i1.8779.

${ }^{20}$ Fazlur Rahman, Islam and Modernity: Tranformation of an Intellectual Tradition (Chicago: University of Chicago Press, 1965), 46.

${ }^{21}$ Ali Musthafa Yaqub, Kritik Hadis (Jakarta: Pustaka Firdaus, 2004), 23.

${ }^{22}$ Samsudin Arif, "Gugatan Orientalis terhadap Hadis dan Gaungnya di Dunia Islam," Jurnal AlInsan 1, no. 2 (2005).

${ }^{23}$ Abdul Fatah Idris, "Studi Pemikiran Fazlur Rahman tentang Hadis-Hadis Pediktif dan Teknis," Wahana Akademika: Jurnal Studi Islam dan Sosial 14, no. 1 (2012), https://doi.org/ 10.21580/wa.v14i1.355.

${ }^{24}$ Rahman, Islam and Modernity, 80. 
indirect. ${ }^{25}$ According to him, predictive hadith(s) appeared because of the conflict of interest in the political field (al-fitān) so it appeared predictions to give benefit to certain political, dogmatic and theological groups.

Rahman traced the existence of predictive hadith that appeared in the book of hadīth, even in Sahīh al-Bukhārī.26 Some characteristic of predictive hadīth could be known according to its redaction and content of the hadith. The redaction of predictive hadith s usually uses forecast narration, like the word satakūnu (ستكون), sayakūnu (سيكون), yakūnu badīy (يكون بَغْبي), saya'tīy (سياتني).

Ulama divide hadīth on the End of the Time (ākhir al-zamān) into two types: first, small signs and second big signs of the End of the Time. Small signs (ashrat shughrā), are signs that preceded the End of the Time with a long time (distance) and become something repeatedly (commonly happen). It is like the losing of knowledge, the spreading of stupidity and alcohol, competing to heighten building, etc. Sometimes, some of the signs are coming togetherly with big signs (ashrat al-kubrā) of the End of the Time or (some of them) occur after one another. Second, big signs (ashrat al-kubrā), are something big that appear just before the End of Times (qurbā qiyām al-să'ah), the occurrence of the big signs are not repeated. It is like ad-Dajjāl coming, Isa's stepping off, and Ya'juj and Ma'juj coming out, the rising sun from the west. ${ }^{28}$

Hadith s of the small End of the Time like the battle in Sham which is in Sunan Abī Dāwud. It is like in Abu Hurairah hadīth, that prophet said: "The End of Times will not happen so the two large groups of massacres occured even though both are one invitation until the coming of liars which more or less are thirty people, all of them claimed to be Allah's messengers until the knowledge is lifted, a lot of shocks, the times feels so short, fitna appears everywhere, and many al-haraj, it is murder, until abundant and excessive wealth is around you, so the wealth people try to find someone who wants to receive their alms, so they offer their alms, but people they offered refuse with saying 'I don't need your alms', so people are competing to heighten building so that a person passes

${ }^{25}$ Rahman, 46.

26Idris, "Hadis Prediktif dalam Kitab al-Bukhari."

${ }^{27}$ Idris, "Studi Pemikiran Fazlur Rahman tentang Hadis-Hadis Pediktif dan Teknis.”

28‘Auḍ bin 'Ali bin 'Abdullāh, Mukhtașar Ashrāṭ al-Sā’ah al-Sughrā wa al-Kubrā (Riyāḍ: Dār alWațan li al-Nașr, n.d.). 
someone's grave and says; ' $O$ if I were replace him/her', till the sun rises from the west, where if the sun has risen from the west and people see it, they all believe, at that time as the verse; 'When it doesn't use anymore for someone's faith, whom he doesn't believe before yet or doesn't do something good yet with his faith."29 The End of the Time occurs when two people have given their both clothes but both of them didn't make trading, both of them didn't fold, and the End of Times occur when someone has gone home and brought kinds of milk but she/he didn't drink it, and the End of Times occur when someone has lifted his/hand to eat but she/he didn't eat it." 30

Hadith of the big signs of the Dajjāl also exists in Islam virtue. Among controversial hadīth is hadīth of Prophet Muhammad prediction about Dajjāl and Imām Mahdi. There are many hadīth(s) on Dajjāl and Imām Mahdi that redactional seems contradictory. This redactional contradiction causes the difference in its understanding (interpretation). Among the experts, there is a sharp dispute in understanding hadīth(s) and understanding the nature of Dajjāl and Imām Mahdi. All this time Dajjāl and Imām Mahdi have been understood as the creature with the physical description as they were described in hadith textually. Along with that, some Muslim refused Dajjāl and Imām Mahdi with the reason that hadith(s) about both of them were problematic hadith. The understanding of hadith textually presents the understanding of Dajjal and Imām Mahdi with a mythical understanding. As a result, there are many Muslims believe Dajjāl and Imām Mahdi coming with distorted belief. Muslims wait for the uncertainty coming of Dajjāl with all of his superiority. As well as uncertainty waiting of Imām Mahdi coming.

The prediction of Imah Mahdi coming has been debated for a long time in Islamic literature. One of the experts who refused the existence of Imām Mahdi was Ibn Khaldun. Ibn Khaldun in his book al-Muqaddimah, mentioned six big factors why hadith s about Imah Mahdi should be rejected by all Muslims in the world. He explained his reason length and width: first, the hadith narrating (tawatur) was not thiqat. Hadīth about Imām Mahdi had various status, there were șahịh, hasan and not a little also categorized as da'îf. $3^{1}$ However, according

${ }^{29}$ QS. al-An'ām [6]: 58.

${ }^{30} \mathrm{Abū}$ Abdillāh Muhammad bin Ismā'îl bin Ibrāhīm al-Bukhārī, Sahịhh al-Bukhārī (Cairo: 'Ibād al-Raḥmān, 2008), hd. 6588.

${ }^{31}$ Sayyid Țamir 'Hashim al-'Amidy, al-Mahdi al-Muntaz̄ār fi Fikr al-Islāmy (Qom: Markaz alRisālah, 1425), 24-26. 
to him, although most of the haditth were weak (daîff), but because of the number of its narrators, most of the hadith(s) could strengthen one another, and it made the acceptance was considered as valid and became mutawatir. Because of that, he stated that hadīth about Imām Mahdi that consisted of the various level has achieved mutawatir level.

Second, the weakness of the sanad was the real, third, narrator who was not thiqat because of having Shi'ah madhhab. Forth, Ibn Khaldun denied hadìth about Imām Mahdi because of madhhab difference. The difference of kalām, sect and political madhhab, for example, encouraged the emergence of hadith about Imām Mahdi. Ḥadīth narrating that praised Prophet Muhammad and 'Ali ibn Abī Țâlib ancestry or hadìth that seemed Shi'ah. Fifth, there were so many prejudices toward the narrator and hadith themselves. On his prejudice itself, he continuously rejected hadìth about Imām Mahdi. Sixth, the information that stated Imām Mahdi explicitly could not be found in Șaḥịh al-Bukhārī and Șaḥịh Muslim. This reason was considered as the strongest because, in both books of sahịh hadīth, it could not be found hadīth that mentioned Imām Mahdi. ${ }^{32}$

Finally, hadīth about Dajjāl and Imām Mahdi can be more adaptive and implementative that fit the era so it gives guidance in increasing the quality of doing religion. Prediction hadīth about Dajjāl consist of șahịh, hasan, and daîf hadìth, 44 hadìith(s) have been observed, 22 hadīth(s) categorized as șahịh, 7 hadìth categorized as hasan, 7 hadìth(s) categorized as hasan li-ghayrih, and 11 hadìth(s) categorized as ḍaîf. Therefore, generally șahịị and hasan hadīth could be made as hujjah about Dajjāl.

\section{Dajjāl as Fitna in Digital Media}

Regardless of the hadith status of the small and big sign of the End of the Time, there is belief and prediction from hadith about the coming of fitna at the End of the Time. Fitna comes from the word al-fitnah which means entering gold into the fire so it will separate the good and the bad one, it also means entering humans into the fire. ${ }^{33}$ Fitna also means disaster and test. It is stated that fitna also means burning something with fire. It also means darkness and injustice, also means prided themselves on something, also means misleading, fitna also

\footnotetext{
${ }^{32}$ Ibn Khaldūn, The Muqaddimah: An Introduction to History, ed. N. J. Dawood, trans. Franz Rosenthal (Princeton: Princeton University Press, 2015).

${ }^{33}$ al-Raghīb al-Ashfahanī, "Fatana," al-Mufradāt fi Gharīb al-Qur'ān (Maktabah Nazar Muștafāā al-Bāz, n.d.), 371.
}

JURNAL THEOLOGIA — Volume 30, No. 2, December 2019 
means mad, also means embarrassment, also means punishment, also means a battle between humans. Fitna in the context of the End of the Time (ākhir alzamān) means chaos, while al-fitān the plural form of fitna, means trial and examination. ${ }^{34}$ Then (this word) often be used to refer to something containing hated tests. And then fitna is identified with all hated things or something that comes back to its, like sin, kufr, murder, burning and all other hated forms. ${ }^{35}$

Related to hadith on the End of the Time there are two fitna phenomena: first, chaos (fitna). The description of this fitna is based on the report from hadith spread that among the signs of the End of the Time is the emergence of big fitna that confuses between haqq and bäțil. So there is a shock on someone's faith. Our Prophet describes that someone's faith can change instantly: 36

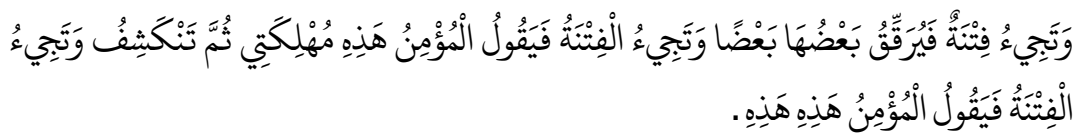

Every time fitna appears, (at that time) faithful person said, "This is what destroyed me" and then opens and appears another (fitna), so he said, "This is destroyed me." 37

Those fitna(s) appear around people until the End of the Time occurs. It is based on the information from Prophet in the hadīth narrated by Bukhārī. From Abu Hurairah he said: "Our Prophet said:

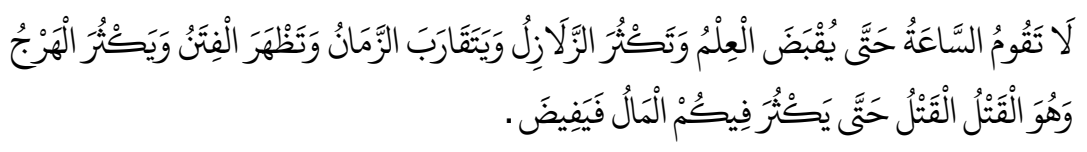

"The End of the Time (ākhir al-zamān) will not occur except after the loss of knowledge, a lot of earthquakes, time seems to run fast, appears various fitna (chaos), al-haraj (murder) and abundant wealth to you." ${ }^{38}$

${ }^{34}$ Muhammad bin Mukrim bin 'Ali Abū al-Faḍl Jamāl al-Dīn Ibn Mandhūr, Lisān al-'Arab (Beirut: Dār al-Shadir, n.d.), 344-46.

${ }^{35}$ Marfat binti Kāmil bin Abdullāh Usrah, al-Manhaj al-Shāri' fi Muwajahat al-Fitān (Qatar: Sunnah Qatar, n.d.), 10. versa.

${ }^{36}$ Someone who in the morning is in faith but in the evening he becomes unbeliever and vice

${ }^{37}$ al-Bukhārī, Șaḥịh al-Bukhārī, hd. 3431.

38al-Bukhārī, hd. 978. 
Among fitna(s) of the End of the Time that have been explained by prophet is a lot of chaos between humans, and al-haraj that is meant is the outbreak of murder as prophet stated: "Indeed before the End of the Time arrives, there will be days or period in which ignorance is rampant, and religious knowledge is lifted (or withdrawn). And there will be various forms of al-haraj (chaos). Chaos that is meant is al-qatl (murder)." Because of many murders occur in Muslim at End of the Time in which those who kill and those who are killed don't know the cause of the murder. According to prophet hadith, it is obtained detail information about this chaos: "For God's sake that my soul is in His hands, End of the Time will not occur so comes a day to the humans, where a person who kills does not know why he kills, and a person who is killed does not know why he is killed". And then it is said to Prophet Muhammad, "why does it happen?" Prophet Muhammad answered, "Al-haraj (chaos), killer and the one who is killed, both of them go to hell."

Chaos (fitna) was illustrated in digital media by various descriptions. It was like the lifting Qur'an. What was meant by the lifting of the Qur'an was the lifting (withdrawn) of religious knowledge. So humans will not get hidāyah or guidance from Al-Qur'an. Along with that ulama is also lifted. This informs that religious knowledge is very related to the faith and quality life of humanity destroyed. This will cause the spreading of the chaos of morality. Humans will only believe in their lust.

Chaos (fitna) was also illustrated by hunger and poverty that spread. This is caused by the global conspiration of unbelievers at the End of the Time so Muslims are in hunger and poverty. The Hadith states that Islam enemies boycott Muslim country's citizens, so Muslim people lack food and medicine. Muslims are also blocked to do trading to the world. ${ }^{39}$ Facing this situation, Muslims have no choice, except to go back to the ancestor life patterns that are very simple, back to nature, date, and camel or sheep milk..$^{40}$ Poverty and hunger were illustrated by the conflict that happened in Suria and Palestine. In other words, the illustration that was described in social media in this context was related to the conflict and war that happen in Sham region (Suria, Lebanon, and Palestine). From the illustration, it could be described that fitna was already

${ }^{39}$ al-Naisyabūry, Șaḥị̣ Muslim, hd. 5189.

${ }^{40}$ al-Naisyabūry, hd. 5156; Abū Dāud Sulaimān ibn al-Ash'ath al-Sijistānī, Sunan Abī Dāwud (Beirut: Muassasah al-Rayyān, 1998), hd. 2639. 
occurred and became the signs of the End of the Time which are proven to occur in the present.

The next of chaos (fitna) is the frequent earthquakes that destroy human civilization. One of the signs of the End of the Time is the frequent earthquakes. There were some nash that explain this. The hadith informed that End of the Time would not occur before the earthquake destroys the earth. As it was narrated by Bukhārī: "There will be no the End of Times until the frequent earthquakes". Even in another narration, it was mentioned that earthquakes occurred in a long time for some years. ${ }^{41}$ Ibn Ḥajar al-Asqalani also explained earthquakes occur almost all over the world. ${ }^{42}$

Those earthquakes were not only illustrated as natural phenomena, such as the movement of the earth's plates and others, but for people who believe, earthquakes were not only a natural disaster, but it was also a warning sign from Allah as the sign of End of the Time. Allah sent earthquakes and disasters as a warning to humans. "And we don't give those signs but to frighten". 43

Second, Dajjal fitna. Dajjal fitna is the biggest fitna in the End of the Time that shakes the minds of intelligent people. May Allah save us. Prophet Muhammad said, "There was no creature since Adam was created until End of the Time who was bigger than Dajjäl". In another narration, it was mentioned that no fitna was bigger than Dajjāl fitna.

This hadith was also illustrated in digital media by sourced on the matn of the hadīth. The things that were illustrated were: first, Dajjāl's appearance. Dajjāl was illustrated as a human who had one eye. In his forehead, it was written the Arabic letters $K a, F a, R a$. This illustration is based on hadith that is narrated by Anas bin Malik that Prophet said: "There is no prophet except to warn his people about Dajjāl. He is blind, liar, know he is blind, while your Rabb is not. It is written between Dajjāl's two eyes: Kaf, Fa, and Ra. It is Kafir." ${ }^{44}$

Second, Dajjāl's ability. Media illustrated Dajjāl as a figure who can attract many people. However, all that attraction is a hoax. Therefore, many people are

41al-Hāêz Abū Abdillah Muhammad ibn Yazīd ibn Mājah al-Qazwīnī, Sunan Ibn Majah (Cairo: Dār al-Hadìth, 1998), 654. 31: 93-94.

${ }^{42}$ Ibnu Hajar al-Asqalani, Fathul Bari, trans. Amiruddin (Jakarta: Pustaka Azzam, 2011), Book

${ }^{43}$ QS. al-Isrā' [17]: 59.

44 al-Bukhārī, Șaḥịh al-Bukhārī, hd. 6883; al-Naisyabūry, Șaḥị̣ Muslim, hd. 5223. 

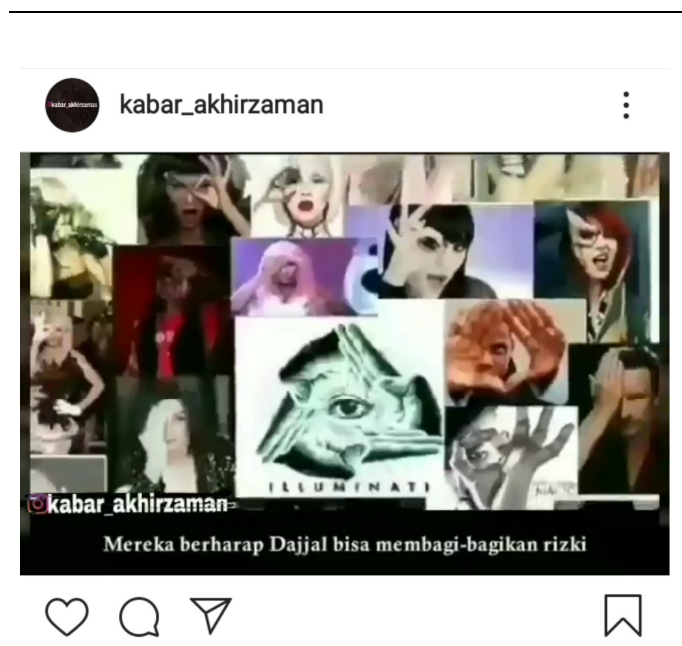

39.206 tayangan

kabar_akhirzaman @kabar_akhirzaman

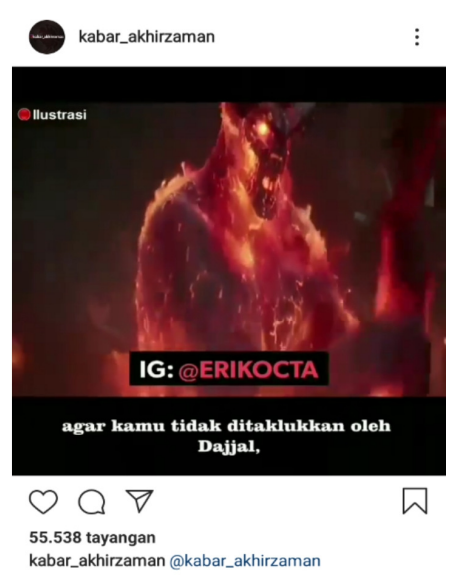

kabar_akhirzaman@kabar_akhirzaman

deceived by Dajjāl's deception. This illustration was based on hadīth that was narrated by Bukhari and Muslim. Sanad of the hadìth is also categorized as Shahih. Third, how to deal with Dajjāl. In digital media was not only informed about Dajjāl and his ability. But it was also related to deal with Dajjāl. One way to avoid fitna of Dajjāl is by reading the first 10 verses of surah al-Kahfi.

\section{E. Implications of Dajjāl Illustration}

The understanding and belief of the Dajjāl in the present context create continued religious behavior in society, especially in Indonesia. Those problems are polarized randomly in every life aspect. At least some phenomena appear from this understanding. First, the phenomenon of society with the emergence of al-Mahdi in this modern era occurs in Indonesia. Al-Mahdi is believed as humans savior from kufr and Dajjāl fitna. Even in the hadìth, it is mentioned that Prophet Isa is sent down to earth and becomes al-Mahdi follower to encounter Dajjāl in the big war. The mythology of al-Mahdi makes him a central figure at the End of the Time discourse. This central role of al-Mahdi encourages some people to claim as Al-Mahdi. This occurs in Indonesia. For instance Winardi, a resident from Sawangan, Depok. It was known by netizen after the viral of an Open Invitation of Trisula Weda's Big Family for halal bi halal on Eid Al-Fitr $1440 \mathrm{H}$ open house with Imām Mahdi. The invitation then was uploaded and viral in Instagram social media: @info_depok. Even it was known that Winardi 
has already had 70 followers. Winardi claimed himself as Imām Mahdi began from his dream. He claimed himself as Imām Mahdi by the grace of Allah after carrying out His commands through dreams. With that dream's journey, Winardi was also claimed could cure people. 45

Second, the spreading of hadith on the End of the Time without sufficient knowledge also increases religious behavior in Indonesia. Like the justification of hadìth by the phenomenon of labeling others with Dajjāl, unbeliever, etc. As Imām Mahdi, Dajjāl is also a central figure in the hadìth on the End of the Time. As a figure of contrast, Dajjāl labeling spreads in Indonesia. Everything that has power and is considered bad is claimed as fitna of Dajjāl.

The problem demands the need to do critical study toward the predictive hadīth about Dajjāl and Imām Mahdi. The critical study is intended as a sharp investigation towards some hadith to make sure the authenticity and authority of Prophet narration. With intertextual interpretation, the nature of Dajjall according to hadith is the symbol of crime. Symbol of crime toward the condition that full of inequality due to the dictator leader, corrupt officials, or due to the spreading of misguided and misleading understanding and ideology. As about Imām Mahdi, no hadīth found that can be used as hujjah (evidence).

The implication of the understanding of hadith toward the diversity that the nature of Dajjāl as the symbol of crime requires Muslims to respond it as a test of faith, and requires strengthening the good deed with three agendas. First, tașl fahmi al-Isläm (the originality of understanding Islam) which covers: Coming back to al-Qur'an and Prophet's sunnah; Islam as a comprehensive and universal system (kämil wa shumul); Strengthen the understanding of Islam moderate. Second, ittihād ummat al-Isläm heading to the unity of Muslims. Third, tajdìd fahmi al-Isläm (renewal of Islamic understanding). The implication of this study is expected to give a big contribution in giving the certainty status of hadith on Dajjāl and Imām Mahdi and the right meaning, so it makes a solution to end to the controversy that has occurred. More than that, this study is expected to straightening the understanding of Muslims about the nature of Dajjāl according to hadith so it gives the guidance to increase the quality of doing religion. Second,

${ }^{45}$ Cynthia Lova and Dian Maharani, "4 Fakta tentang Winardi yang Mengaku sebagai Imam Mahdi Di Depok," Kompas.Com, May 31, 2019. 
Muslim society has to be wise in justification of the hadith on the End of the Time don't let the unity of the people is disturbed by claiming the truth and labeling munkar to each other.

\section{F. Conclusion}

Seeing the massive phenomenon of the illustration of the hadìth on Dajjāl in the YouTube media, we can state that the mediatization of Islamic doctrine indicates a change in the role of the media in the $D a^{\prime} w a h$ and teaching of the hadìth on Dajjāl in Indonesia. The illustration of the hadìth on Dajjāl had become an indication of the widespread role of the media in the spread of Islamic material, and its changing role from being dominated to dominating the logic of religion. Where the illustration of the hadìth on Dajjāl on Youtube has formed a new pattern in the understanding of hadith from abstract-imaginative to concrete-imaginative. This is can be seen from the illustration of the Dajjajl as follows:

Digital media illustrates fitna in two phenomena: first, chaos (fitna) and second, fitna of Dajjall. Fitna is illustrated always presenting the condition of the world in chaos (al-haraj) and full of intrigues. In that fitna period, the right (alhaqq) and wrong (al-bätili) scales are hard to know clearly. Therefore, this condition makes someone's faith is very fragile. Digital media illustrates this as the broken scales. Then this condition is getting chaotic with the presence of a figure who is known as Dajjāl. Dajjāl is a figure who could attract so many people to follow him with his full of deception. Digital media is not only illustrated the profile of Dajjāl but also how to deal with him.

With this, it can be seen that the hadith on Dajjāl is not only predictive but also very technical and detail. It might be doubted by Fazlur Rahman. Besides, discourse about the hadìth on Dajjāl sometimes takes side to only one of madhhab group in Islam. It is like the coming of Imām Mahdi from the Quraysh tribe. It indicates that the leadership that is worth waiting for in the a akhir alzamān is from the Quraysh group. Therefore, this hadīth is rejected by some experts like Ibn Khaldun.

The status of the hadīth on Dajjāl which are șahịh and included in șahịh books of hadīth like al-Bukhārī and Muslim. But we also are critical and understand this hadith proportionally. This will avoid the existence of claims and Dajjāl and Imām Mahdi justification by and for certain people.] 


\section{BIBLIOGRAPHY}

'Abdullāh, 'Auḍ bin 'Ali bin. Mukhtașar Ashrāt al-Sā'ah al-Sughrā wa al-Kubrā. Riyāḍ: Dār al-Wațan li al-Nașr, n.d.

al-'Amidy, Sayyid Țamir 'Hashim. Al-Mahdi al-Muntazar fi Fikr al-Islāmy. Qom: Markaz al-Risālah, 1425.

al-Ashfahanī, al-Raghīb. "Fatana." al-Mufradātfi Gharīb al-Qur'ān. Maktabah Nazar Mușțafā al-Bāz, n.d.

al-Asqalani, Ibnu Hajar. Fathul Bari. Translated by Amiruddin. Jakarta: Pustaka Azzam, 2011.

Arif, Samsudin. "Gugatan Orientalis terhadap Hadis dan Gaungnya di Dunia Islam." Jurnal Al-Insan 1, no. 2 (2005).

al-Bukhārī, Abū Abdillāh Muhammad bin Ismā'îl bin Ibrāhīm. Ṣaḥịh al-Bukhārī. Cairo: 'Ibād al-Raḥmān, 2008.

Bakhtyar, Maryam. "Adaptation and Comparison of Dajjal (Antichrist) in Islam with in Christianity." Journal of Islamic Studies and Culture 2, no. 2 (2014): 71-81.

Fakhruroji, Moch. "Mediatization of Religion in 'Texting Culture': Self-Help Religion and the Shifting of Religious Authority." Indonesian Journal of Islam and Muslim Societies 5, no. 2 (December 10, 2015): 231. https://doi.org/10.18326/ijims.v5i2.231-254.

Fatkhullah, Faiz Karim, Tajudin Nur, and Undang Ahmad Darsa. "The Reception of Dajal Story in the Saifu Ad-Dharib." Humanus: Jurnal Ilmiah Ilmu-Ilmu Humaniora 17, no. 1 (2018): 37-52. https://doi.org/10.24036/ humanus.v17i1.8779.

Hasan, Hadri. "Contemporary Religious Movement in Indonesia: Study of Hijrah Festival in Jakarta in 2018." Journal of Indonesian Islam 13, no. 1 (2019): 230-65. https://doi.org/10.15642/JIIS.2019.13.1.230-265.

Heryanto, Ariel. Identity and Pleasure: The Politics of Indonesian Screen Culture. Singapore: National University of Singapore (NUS) Press, 2014.

Ibn Mandhūr, Muhammad bin Mukrim bin 'Ali Abū al-Faḍl Jamāl al-Dīn. Lisān al'Arab. Beirut: Dār al-Shadir, n.d. 
Idris, Abdul Fatah. "Studi Pemikiran Fazlur Rahman tentang Hadis-Hadis Pediktif Dan Teknis." Wahana Akademika: Jurnal Studi Islam dan Sosial 14, no. 1 (2012).https://doi.org/10.21580/wa.v14i1.355.

_—_. "Hadis Prediktif dalam Kitab al-Bukhari." Jurnal Theologia 24, no. 1 (2013): 285-306. https://doi.org/10.21580/teo.2013.24.1.325.

Istriyani, Ratna, and Yuliatun Yuliatun. "Media: Causes and Strategies to Overcome Islamophobia (Psychological and Sociological Study)." QIJIS (Qudus International Journal of Islamic Studies) 4, no. 2 (2016): 2012017. https://doi.org/10.21043/qijis.v4i2.1759.

Khaldūn, Ibn. The Muqaddimah: An Introduction to History. Edited by N. J. Dawood. Translated by Franz Rosenthal. Princeton: Princeton University Press, 2015.

Lova, Cynthia, and Dian Maharani. "4 Fakta tentang Winardi yang Mengaku sebagai Imam Mahdi di Depok." Kompas.Com, May 31, 2019.

Lundby, K. "Mediatization as Key." In Mediatization: Concept, Changes, Consequences. New York: Peter Lang, 2009.

Müller, Johannes. Perkembangan Masyarakat Lintas Ilmu. Jakarta: Gramedia Pustaka Utama, 2006.

Mulyono, Agus. Kasus-Kasus Aktual Kehidupan Keagamaan di Indonesia. Jakarta: Badan Litbang dan Diklat Puslitbang Kehidupan Keagamaan Jakarta, 2015.

Musthofa, Musthofa. "Prinsip Dakwah via Media Sosial." Aplikasia: Jurnal Aplikasi Ilmu-Imu Agama 16, no. 1 (2016): 51-55. https://doi.org/10.14421/ aplikasia.v16i1.1175.

al-Naisyabūry, Muslim bin al-Ḥajjāj Abū al-Ḥasan al-Qusyairy. Ṣaḥịh Muslim. Beirut: Dār al-Fikr, n.d.

Omar, Faradillah Iqmar, Nor Azlili Hassan, and Iza Sharina Sallehuddin. "Role of Social Media in Disseminating Dakwah (Peranan Media Sosial dalam Penyebaran Dakwah)." In Islamic Perspectives Relating to Business, Arts, Culture and Communication, edited by Roaimah Omar, Hasan Bahrom, and Geraldine de Mello, 43-55. Singapore: Springer Singapore, 2015. https://doi.org/10.1007/978-981-287-429-0_5.

Purwanto, Yedi, Muhamad Taufik, and Asep Wawan Jatnika. "Peran Teknologi Informasi dalam Perkembagan Dakwah Mahasiswa." Jurnal Sosioteknologi 
16, no. 1 (2017): 94-109. https://doi.org/10.5614\%2Fsostek.itbj.2017. 16.1.8.

al-Qazwīnī, al-Ḥāfiz Abū Abdillah Muḥammad ibn Yazīd ibn Mājah. Sunan Ibn Majah. Cairo: Dār al-Ḥadīth, 1998.

Rahman, Fazlur. Islam and Modernity: Transformation of an Intellectual Tradition. Chicago: University of Chicago Press, 1965.

al-Sijistānī, Abū Dāud Sulaimān ibn al-Ash'ath. Sunan Abì Dāwud. Beirut: Muassasah al-Rayyān, 1998.

Sumadi, Eko. "Dakwah dan Media Sosial: Menebar Kebaikan tanpa Diskrimasi." At-Tabsyir: Jurnal Komunikasi Penyiaran Islam 4, no. 1 (2016): 173-90. https://doi.org/10.21043/at-tabsyir.v1i2.2912.

Syahputra, Iswandi. "Agama di Era Media: Kode Religius dalam Industri Televisi Indonesia." Esensia: Jurnal Ilmu-IImu Ushuluddin 17, no. 1 (2016): 125-38. https://doi.org/10.14421/esensia.v17i1.1283.

Ushanova, Irina A. "Mediatization of Communication: From Concept to Theory." Journal of Siberian Federal University. Humanities \& Social Sciences 11, no. 8 (2015): 2703-12. https://doi.org/10.17516/1997-1370-2015-8-112703-2712.

Usrah, Marfat binti Kāmil bin Abdullāh. Al-Manhaj al-Shāri' fi Muwajahat al-Fitān. Qatar: Sunnah Qatar, n.d.

Wuryantai, AG. Eka Wenats. "Digitalisasi Masyarakat: Menilik Kekuatan dan Kelemahan Dinamika Era Informasi Digital dan Masyarakat Informasi." Jurnal Ilmu Komunikasi 1, no. 2 (2004): 131-42. https://ojs.uajy.ac.id/ index.php/jik/article/view/163.

Yaqub, Ali Musthafa. Kritik Hadis. Jakarta: Pustaka Firdaus, 2004. 